\title{
GOVERNANCE: EXPLORING THE ISLAMIC APPROACH AND ITS RELEVANCE FOR THE MODERN CONTEXT
}

\author{
Mohammed Veqar Ashraf-Khan ${ }^{1 *}$, Mohammad Shahadat Hossain ${ }^{2}$ \\ 10 pen University of Mauritius, Réduit, Mauritius \\ 2Department of Law Bangladesh Islami University, Dhaka, Bangladesh \\ Corresponding author E-mail : mohammedvak@hotmail.com
}

\begin{abstract}
Managing this wealth (amanah) leads to the basic concept of Islamic accountability where proper disclosure and transparency in every business transaction or service is encouraged. This paper attempts to explore the characteristics and application of the principles of Islamic governance. Using qualitative research methods, this study further focuses on trust and accountability with respect to governance mechanisms as require d by Islamic principles and in light of today's world affairs. As a doctrinal research, the researcher reviews the relevant literature to identify the main features of government such as shura, caliphate, accountability, transparency, justice and equality as well as the current need for trustin public and private government. The findings of this study are that the Koran and the Sunnah of the Prophet Muhammad (SAW) have provided many guidelines in the field of constitutional affairs that can help the government system. The Qur'an is flexible enough not to mention the details and details that are left for Muslims to formulate according to their particular circumstances. Finally, the aim of this paper is to inform policy makers and practitioners about the main doctrines that have been proposed by the Qur'an and which can be applied for the effective management of our affairs.
\end{abstract}

Keywords: governance, Islam, trust, transparency, accountability, stakehold ers

\section{INTRODUCTION}

Citizens often perceive the economic, governance, social and institutional implications of actions to improve law and justice, strengthen local and long-term public structures, and have implications for the quality of life of the community. as a country that exists vis-à-vis international or regional organizations, including the agencies of the United Nationsand the World Bank (Hopper, 2017; Lerman \& Weaver, 2014). However, the efforts made by the government are costly where there is no guarantee that they will be successful. These disadvantages include: greater administrative costs, potential isolation, barriers and rivalries between the institutions (e.g. law enforcement officers, prosecution officials, auditors and inspectors). For instance, there are fiscal and economic costs of regulation, namely:

"Administrative financing, fiscal, regulatory systems, adjudication for business, new equipment, construction, production, relocation, permits, to competition and innovation as well as reducing investment (Snider \& Rendon, 2012).

If these negative perceptions in respect of governance structures are not managed, the local population easily turns to open hostility towards compliance to procedures, with refusal to recognise their legitimacy and in due course contributing to its ineffectiveness (Welter \& Smallbone, 2011). This paper examines broad issues of governance, namely: concept of governance; Islamic perspectives on governance; the position of Amanah in Shariah (Islamic law); violation of Amanah and its consequences; current global crisis in governance and finally identifying Islamic Principles of governance in public

* Copyright (c) 2021 Mohammed Veqar Ashraf-Khan, Mohammad Shahadat Hossain

This work is licensed under a Creative Commons Attribution-ShareAlike 4.0 International License.

Received: December 5, 2020 ; In Revised: January 16, 2021; Accepted: 26 January, 2021 
administration (Zürn, 2018). For each of these issues of governance, the underlying causes and effects are identified.

Several previous studies on Islamic governance such as research conducted by Elghuweel (2017), conducted research with the aim of discussing the impact of corporate governance (CG) and Islamic (IG) mechanisms on corporate earnings management (EM) behavior in Oman, Hamid (2011) conducted a study with the aim of discussing what factors contribute to the type of isolation in Islamic companiesand financial institutions for Islamic governance from these two economic crises, Lewis (2014) conducted a study with the aim of the principles in Islamic Institutions. In this study, the authors took the latestobjects and datawhich are expected to be used in theformation of policies in Islamic governance.

\section{METHODOLOGY}

This paper explores broader means and more specifically the Islamic perspective to find effective ways to move towards effective implementation of governance procedures and generate wider acceptance by the citizens. To achieve this aim, a literature review approach was adopted so as to synthesise, previous contributions in a subjective and narrative fashion (Denyer \& Tranfield, 2006). Before embarking on the literature review, articles were collected that addressed the extensive issues of governance, challenges for implementation as well focusing on the Islamic perspectives. Forward and backward tracking of citations was used to further complement the research efforts. The articles used for this study were retrieved from the academic and research databases, namely, EBSCO, Emerald, Sage, JSTOR, SSRN, ERIC, ScienceDirect and Taylor and Francis. Subject headings, author names and keywords were used to search for relevant sources. The keywords used included: "governance", "governance challenges", "Islamic perspective on governance" and related words. As this study revolves around the Islamic principles, the main sources were the Holy Quran and the collection of Ahadith. These were consulted and the specificverses were read in Arabic, English and French to gain maximum understanding of the underlying principles. As the literature progressed, one landmark document "Maximizing stakeholders' interests: An empirical analysis of the stakeholder approach to corporate governance" by Ayuso et al (2014), laid the foundation for this paper and was studied in-depth. To corroborate, other articles which expanded on Ayuso et al (2014) were also perused to obtain better explanations of the stakeholder concept.

\section{RESULT AND DISCUSSION}

\section{Governance And Its Challenges}

Governance is derived from the Latin word gubernare meaning to steer or to govern. Beyond this simple meaning, there are many variations in respect of the definition of governance, subject to diverse interpretations byscholars, researchers and practitioners, hinting at the complexity of this concept (Hufty, 2011; Robichau, 2011).A cursory perusal of the definitions indicate some common features: governance deals with institutional processes and can cover areas of politics, economy, social justice and public administration. For the purpose of this study, the International Monetary Fund's (IMF) definition is chosen as it focuses on "transparency". According to the IMF (2005), governance relates to two important spheres:

"improving the management of public resources (and) supporting the development and maintenance of a transparent and stable economic and regulatory environment conducive to efficient private sector activities."(IMF, 2005) 
IJIK, Vol.11 No. 1: 29-40

Governance: Exploring the Islamic approach and its relevance for the modern context Mohammed Veqar Ashraf-Khan, Mohammad Shahadat Hossain

Different countries possess different governance structures based on their local dist inctiveness (Devine-Wright, 2011). typology of political systems (see Table 1 below) provides insight into the specific characteristics of the political systems which help to understand the environment within which the governance procedures (or lack of them) arelikely to occur.

Table 1. typology of political systems

\begin{tabular}{|c|c|c|c|c|}
\hline $\mathbf{N}$ & $\begin{array}{c}\text { Types of political } \\
\text { systems }\end{array}$ & Characteristics & $\begin{array}{c}\text { Degree of state } \\
\text { legitimacy }\end{array}$ & $\begin{array}{c}\text { Types of policies in } \\
\text { place }\end{array}$ \\
\hline 1 & Collapsed states & $\begin{array}{l}\text { No effective central } \\
\text { government }\end{array}$ & $\begin{array}{l}\text { less - until it has not } \\
\text { mastered the powers that } \\
\text { exist outside the state }\end{array}$ & No policies \\
\hline 2 & Personal rule & $\begin{array}{l}\text { political parties are } \\
\text { selected based on } \\
\text { personality }\end{array}$ & $\begin{array}{l}\text { lacking - power is used to } \\
\text { enrich on eself and there } \\
\text { is frequent strife }\end{array}$ & $\begin{array}{l}\text { policies are less } \\
\text { stable, few basic } \\
\text { public services are } \\
\text { provided and the } \\
\text { main objective is to } \\
\text { enrich those in power. }\end{array}$ \\
\hline 3 & $\begin{array}{c}\text { Minimally } \\
\text { institutionalised } \\
\text { states }\end{array}$ & $\begin{array}{l}\text { Bespite poor functioning } \\
\text { The basic rules of the } \\
\text { game are laid down in law } \\
\text { and practice. }\end{array}$ & $\begin{array}{l}\text { less / medium - without } \\
\text { consensus on institutions } \\
\text { to resolve conflicts but } \\
\text { conflicts over the right to } \\
\text { hold power persist }\end{array}$ & $\begin{array}{c}\text { providing various } \\
\text { public services and } \\
\text { basic welfare but still } \\
\text { based on patronage }\end{array}$ \\
\hline 4 & $\begin{array}{l}\text { Institutionalised, } \\
\text { non-competitive } \\
\text { states }\end{array}$ & $\begin{array}{c}\text { there is no open } \\
\text { competition for power, } \\
\text { Organizing through stable } \\
\text { and legitimate } \\
\text { organizations and } \\
\text { procedures, political } \\
\text { parties serve the regime }\end{array}$ & $\begin{array}{l}\text { moderate - often with big } \\
\text { questions about the roots } \\
\text { of legitimacy not based } \\
\text { on the day-to-day } \\
\text { approval and legitimacy } \\
\text { to carry out activities, }\end{array}$ & $\begin{array}{c}\text { citizens have little } \\
\text { influence on the range } \\
\text { and type of provision } \\
\text { the organization } \\
\text { provides }\end{array}$ \\
\hline 5 & $\begin{array}{c}\text { Institutionalised, } \\
\text { competitive states }\end{array}$ & $\begin{array}{l}\text { open competition for } \\
\text { power through the parties } \\
\text { in a planned and } \\
\text { regulated manner through } \\
\text { stable and legitimate } \\
\text { organizations and } \\
\text { procedures }\end{array}$ & $\begin{array}{l}\text { has great legitimate } \\
\text { power to make decisions } \\
\text { and hold power until in } \\
\text { the context of conflict. }\end{array}$ & $\begin{array}{c}\text { The main theme in } \\
\text { politics is diverse } \\
\text { basic services and } \\
\text { welfare - the types } \\
\text { and types of services } \\
\text { are }\end{array}$ \\
\hline
\end{tabular}

Source: Adapted from Moore (2001)

The interesting point to note in Moore (2001) typology is the prevailing environments and conditions and the implementation challenges faced in those environments. No matter the level of good intentions, implementation of governance procedures is not a straightforward and linear process.

"Unexpected epidemics, abruptcatastrophic shifts in biophysical systems, and economic crises that cascade across national borders and regions are events that challenge the steering capacity of governance atall political levels" (Duit \&Galaz, 2008). 


\section{Administration of tax in a countryalso affects the quality of governance whereby}

"the dependence of states on unearned income is likely to have adverse effects on the quality of governance and.the overall level of taxes does help mobilise citizens politically" (Paler, 2013).

Another significantimpedimentissystemic corruption even though corruption "is not the sum-total of governance, but rather one important indicator of it (Moyo, 2017). Consequently, the level of corruption (e.g. throughindices such as Transparency International's 2017 Corruption Perceptions Index (CPI)) can suggest the level of governance especially when read in conjunction with the basic anti-corruption activities undertaken (Ashraf-Khan, 2018; Kim, 2014).

For instance, analysing Muslim-majority countries and their level of governance, it is seen that at the country-level, To adhere to the high moral standards of the Qur'an and the Sunnah of the Prophet Muhammad (PBUH) Muslim-majority countries seem to have great difficulty. This is reflected in the CPI, which shows that there are Muslim majority countries which are the most corrupt countries in the world. In fact, no Muslim country is in the top 20 (least corrupt) rankings and the top five mostethical coun tries in the world are in the order: New Zealand, Finland, Norway, Switzerland, Denmark and Norway (TI (Transparency International), 2017). Another crucial factor that influences the effective functioning of governmentstructuresis the level of trust of citizens (dis) in their government. Consequently.

"trust can facilitate coordination between citizens and with government actors, reduce transaction costs, increase the likelihood of citizen compliance with government demands, and contribute to governmentpolitical support" (Braithwaite \& Levi,1998).

Trustworthy governments (as well businesses) accept that they have obligations and nurture trust and hence are able to prosper in all spheres (Rothstein,2011). Closely linked with trust is accountability where, in the present context, the focus is "on the public character of formal accountability (Bovens etal,, 2014).

While there may be other factors that arelikely to influence citizens' support for government actors and governance procedures, this study focuses on the concept of trust as one effective way to encourage citizens to truly embrace the fundamental principles of governance by correlating these principles to their inherentvalues. The aim of this study is to seek sound principles to resolve the issue of trust and thereby allow social and economic systems to function effectively. The next section will explore this concept of trust through an Islamicperspective.

\section{Islamic Perspective}

The specific objective of this study is to find solutions for governance challenges. Taking an initial wider view of this exploration, it is imperative To understand the fundamental concepts behind all the creations of the universe in which the Holy Quran offers ideological inspiration for the observation of natural phenomena and for the pursuit of scientific science (Bangladesh Institute of Islamic Thought, 2005). It isinteresting to note the importance placed on this quest for knowledge when almostone-eighth of the Holy Quran is "devoted to encouraging people to observe, think and use their intellect to discover the facts and laws of nature, as indicated by the repeated use of the words: Tabassur (understanding) Tafakkur (rationalization), and Tadabbur (observation)" (Bangladesh Institute of Islamic Thought, 2005). Consequently, the Holy Quran, together with the Sunnah of the Holy Prophet Mohammad (SAW), The Islamic socio-scientific epistemological basis forms and is coupled with participatory dialogue between both institutional and other relational organizational entities (Ali, 2011). Islamic principles add value to 
governance issues by emphasising on the "Tawhid'sfundamental epistemology (equality of God= unity of knowledge) applies to all life problems in constantly circular causation and continuity of interrelationships." (Ali,2011).

In fact, Tawhid is the foundation of Islamic faith and as such, is one of the mostimportant pillars of Islamic economics (Chapra, 2016; Choudhury, 2011; Mahomedy, 2013). The following verse from the Holy Quran lays emphasis on the primary belief that everything created by Allah has a purposeand the purpose of human beings is to be the world's vicegerent:

"Men who celebrate the praises of Allah standing, sitting, and lying down on their sides, and contemplate the wonders of creation in the heavens and the earth, (with the thought): "Our Lord! Not for naught Hast thou created all this! Glory to Thee! Give us Salvation from the penalty of the Fire" (Surah al-Imran 3: verse191).

Allah monitors every affairs of human beings and He knows everything all the times (Chapra, 2016). "Verily, Allah is Subtle, Well-Aware" (31:16) and all human beings are answerable to Him and consequently, the principle of Tawhid lays the foundation of governance in Islam.

The Shariah (Islamic law) guided principles and instruments that govern Islamic social and economic conduct are: (1) the extension of Tawhid (unity of knowledge) to the interacting environing factors; (2) The principle of justice as equilibrium and equity; (3) the principle of the efficient inclusion of capital in social and economic activities; and(4) the principle of recursive interaction between the phases referred to above (Choudhury, 2011). "These concepts are true of organizations and institutions in an economy that progress from their initial imperfect standards into an Islamic political economy (Choudhury, 2011). Hence, With the growth of Islamic financial and economic institutions, also within segmented markets, it will become increasingly desirableto receive national funding in order to facilitate the functioning of these institutions, The lack of predatory competition and anti-trustimpacts, combined with sustainable productive success and social benefits, would increase morale (Choudhury, 2011). This concept of generating trust and ultimately support is relevant to governmental bodies.

In respect of Amanah (the Arabic word for trustworthiness), the Holy Quran provides ample directives. In Surah an-Nisa (4: verse 58), it is stated that "Verily, God does command you to render back your Truststo whom they are due."). The term Amanah is explained in Surah al-Ahzaab (33:verse 72), as being "the trust or moral responsibility or honesty and all the duties which Allah has ordained". The rewards for nurturing trust is stated in Surah al-Mu'minoon (23: verses 8 and 10-11), whereby “Those that are faithfully true to their amanah (all the duties ordained by Heaven, integrity, spiritual obligation and trust, etc.) and their covenantsare the inheritors, indeed.". Likewise, the punishments of betraying trust is explained in Surah al-Anfal (8: verse 27) "O believers, betray not God and the Messenger, and betray not your trusts that which has been entrusted to you, in the way of religion or otherwise whileyou are aware". Finally, an overall guidance is provided in Surah Hud (11: verses 85 -86), where it is stated that "And 0 people of mine!."

An important characteristic of a Muslim isbeing trustworthy. The Holy Prophet Mohammad (SAW) was known, even before his Prophethood, to be Al-Amin (the trustworthy one). The Prophetic Sunnah (words and deeds of the Holy Prophet Mohammad (SAW) form "the basic codes or guidelines for the whole of mankind in their drive towards a just and welfare society" (Bangladesh Institute of Islamic Thought, 2005). The Holy Prophet Mohammad (SAW) has laid great emphasis on the fulfilment of trust obligations. Anas (RadhiAllahu anhu) narrated: 
"It must have been a rare sermon indeed in which the Prophet may not have said the following words, "One who does not fulfill trust obligations has no Faith (emaan) with him; and one who does not stand by his word of promise has no religion with him." [Reported by al-Baihaqi in Shu'ab alIman].

The Holy Prophet Mohammad (SAW), explainingthe signs of hypocrisy on a certain day, pointed to a specific sign that was: "Give him an Amanah and he will do khiyanah," according to narratives from Abu Hurairah and Ibn Umar (RadhiAllahu anhum) appearing in al-Bukhariand Muslim.

It is important to note that the Shariah rules are entrenched in the Holy Quran and the Sunnah and hence, make the Islamic entities both market driven as well upholding the principle of social justice and inclusiveness. The shareholders become active participants in the decision-making process as stakeholders, becoming the ultimate framework of the Mudarabah-Musharakah (profit and equity participation) and related cooperative projects through inter-systems and intra-system participation (Choudhury, 2011). For instance, in respect of IslamicFinancial Institutions (IFIs), “Corporate governance based on Shariah is more active than traditional corporate governance in the sense that the board of directors, Shariah committee, accountholders of depositors, investors and regulators have direct interests in the companyoperations and results of the IFIs" (Muhamad Sori et al., 2015).

According to Ibn-e-Khaldun, A effective and sustainable administrative system is one in which the involvement of individuals is assured. What Ibn-e-Khaldun observed is expressed in the modern New Public Administration (NPA) theory that administration should be such as to make individuals believe that in the process of planning, administration and execution they are equal partners (Abbas, 2018).

There is not one exclusive route to trust and inclusiveness. This study submits that Islam presents distinctive values and special characteristics of governance with the objective of upholding the principle of social justice by welcoming participation of stakeholders and which ultimately encourages citizens to be in conformity with governance procedures. The next section will, therefore, elaborate on stakeholders and the effective means to manage their expectations.

\section{Stakeholder Management}

It is important to think about stakeholdersin order to create trustamong stakeholders, which leads to deciding which groups are stakeholders and why, that is, the stakeholder identity issue (Colvin et al,, 2016). The definition of a stakeholder will behelpful beforegoing further. Jobs from various public bodies, sponsors, watchdogs, the media, NGOsand society as a whole are some exam ples of stakeholdersapplying this term can be very useful as it helps to understand the priority and level of attention a particular stakeholder needs (Bendell, 2017). For each stakeholder party, it also helps to choose the right communication strategy. A stakeholder's value is focused on three variables: power, credibility and urgency. The purpose of this model is to recognize, prioritize and actively engage with more relevant or influential stakeholders. Figure 1 below illustrates the various combinations of these attributes and The eight distinct stakeholder groups are listed and defined in Table 2, namely: dormant, latent, requesting, dominant, risky, dependent, definitive and non-stakeholders. 
IJIK, Vol.11 No. 1: 29-40

Governance: Exploring the Islamic approach and its relevance for the modern context Mohammed Veqar Ashraf-Khan, Mohammad Shahadat Hossain

\section{Stakeholder Salience Model}

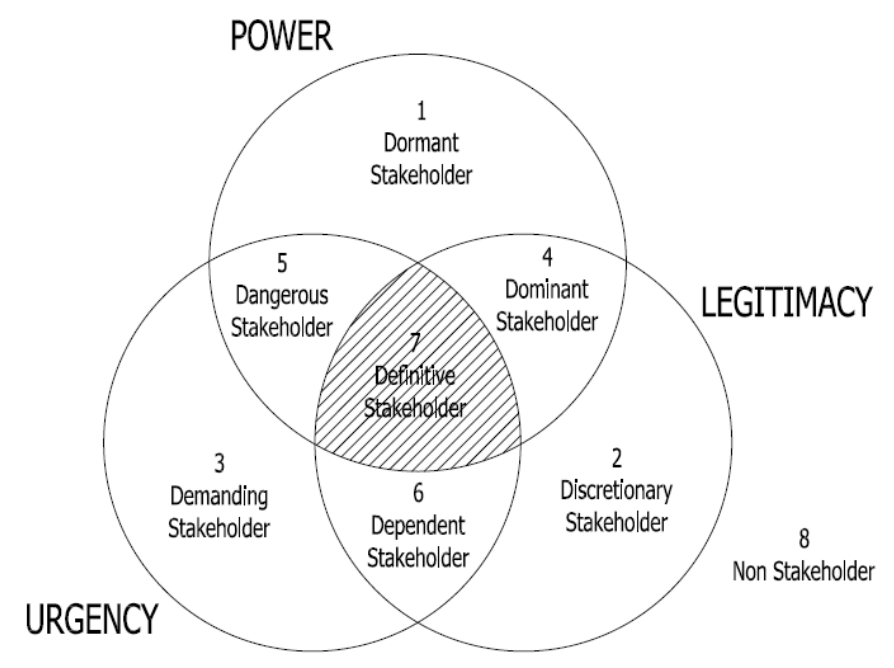

Figure 1. Stakeholder Salience Model. Source: Mitchell et al (1997)

To apply thismodel in practice, the stakeholders need to be assigned to one of the eight categories:

Table 2. Characteristics of the Stakeholders

\begin{tabular}{|c|c|c|}
\hline CATEGORIES & DESCRIPTION & COMMUNICATION STRATEGY \\
\hline 1.Dormant stakeholders & $\begin{array}{l}\text { They have the ability to enforce their will } \\
\text { on others, but authority and urgency are } \\
\text { lacking. }\end{array}$ & $\begin{array}{l}\text { Keep these interested parties } \\
\text { updated. }\end{array}$ \\
\hline 2.Discretionary stakeholders & $\begin{array}{l}\text { They have valid claims, but they have no } \\
\text { auth ority to control the company or to } \\
\text { make urgent claims. }\end{array}$ & $\begin{array}{l}\text { Just involve them if really } \\
\text { necessary (e.g. something is going } \\
\text { very wrong). }\end{array}$ \\
\hline 3.Demanding stakeholders & $\begin{array}{l}\text { There are urgent demands from these } \\
\text { stakeholders, but there is no authority or } \\
\text { legitimacy to implement them. }\end{array}$ & $\begin{array}{l}\text { Take note that you do not waste } \\
\text { too much time keeping them up to } \\
\text { date. }\end{array}$ \\
\hline 4.Dominant stakeholders & $\begin{array}{l}\text { In the company, they have both auth ority } \\
\text { and legitimate statements that give them } \\
\text { strong control on the project. }\end{array}$ & Keep aware of them. \\
\hline 5.Dangerous stakeholders & $\begin{array}{l}\text { Such people have authority and urgency, } \\
\text { but lack legitimacy.. }\end{array}$ & $\begin{array}{l}\text { Keep these stakeholders involved } \\
\text { or fulfilled adequately. }\end{array}$ \\
\hline 6.Dependent stakeholders & $\begin{array}{l}\text { They lack authority, but they have } \\
\text { pressing and credible arguments. }\end{array}$ & $\begin{array}{l}\text { They need to be handled as they } \\
\text { can choose to join with other }\end{array}$ \\
\hline
\end{tabular}




\begin{tabular}{lll}
\hline & & $\begin{array}{l}\text { stakeholders very easily and thus } \\
\text { affect the mission. }\end{array}$ \\
\hline 7.Definite stakeholders & $\begin{array}{l}\text { Such people have authority, credibility } \\
\text { and urgency. }\end{array}$ & $\begin{array}{l}\text { Communication with them is } \\
\text { crucial. }\end{array}$ \\
\hline 8.Nonstakeholders & $\begin{array}{l}\text { They have no jurisdiction, no authenticity } \\
\text { and no urgency. }\end{array}$ & $\begin{array}{l}\text { Do not spend time in any contact } \\
\text { with them. }\end{array}$ \\
\hline
\end{tabular}

Source: Mitchell et al (1997)

The above model has the management and credibility of stakeholders as its theoretical base. The two theories have also been used by political scientists to research the faith of people in government institutions (De Schepper et al., 2014). These theories include multiple viewpoints on the views of stakeholdersand their determinants.

It is possible to record the roots of stakeholders in literature back to the Stanford Research Institute in1963, appearing in an international memorandum, but Freeman (1984) is also credited with bringing stakeholder theory into the management arena with his seminal publication Strategic Management: A Stakeholder Approach (Donaldson \& Preston, 1995). The philosophy of stakeholders has evolved from corporate social responsibility, organizational theory, structure theory and corporate strategy to take legal, social and economic considerations into account. Freeman (1984) The claimed stakeholder theory focuses on the concept of who or what really matters, proposing organizational management techniques that take into account the desires of other parties. Donaldson and Preston (1995) The stakeholder theory, while basically universal, has been shown to be divided into three theoretical taxonomies.:

1. The company's actions and attributes, and its view of others, are descriptive.

2. The objective of this instrumentis to verify the ties between organizations

3. The position of moral guidance for the operation and management of companies is defined in normative terms. Stakeholder theory has often recruited the characteristics of power and interest within thismodel to understand stakeholders.

Power is defined as an organization's capacity to exert its will to achieve the results they want (Saito \& Ruhanen, 2017). Whereas concern refers to levels of focus or participation Similarly, justas others have tried to grasp stakeholders, others have provided many approaches to defining stakeholders. While methods remain somewhat contentious, the principle of credibility is typically central to these schemes. Freeman (1984) It implied that anybody with a stake that can influence the organization should be deemed valid and therefore worthy of consideration, regardless of the exis tence of their arguments. However, Donaldson and Preston (1995) It was of the view that legitimacy seeks to distinguish between those who can impact and those who have a moral argument. On the other hand, George (2014) argued that by These parties, having power irrespective of a moral argument, should not be removed, in accordance with the very principle of stakeholding.

Normative stakeholders'are those whoseamoral responsibility the organization has,' derivative is 'those whose acts and claims must be accounted for by managers because of their possible impact on the organization and its normative stakeholders,' and non-stakeholders are those who have no control or moral argument and can be excluded. Yet, just as this technique represents those with power and those with arguments, George (2014) It may be difficult to differentiate between normative and derivative stakeholders. This study first describes the types of stakeholders that arise from different attribute combinations: control, credibility, and urgency. (see Figure 1. Stakeholder Salience Model). Seven kinds 
are analyzed logically and conceptually, three with just one attribute, three with two attributes, and one with all three attributes. This research proposes that the possession of these attributes by stakeholders can be assessed effectively through more methodological and empirical work.

Returning to Phillips (2003) In separating normative and derivative stakeholders, the principle of authority, contractual relationships and relationships of interpretation of norms, principles and beliefscan be considered to be decisive. This study, using Phillips' (2003) Taxonomy claims that relationships of norms, values and beliefs are subjective on the assertion that these perceptions vary depending on the position. Traditionally, the private sector is driven by returns and benefits and thus holds different views of the public sector, usually seeking better social well-being. Examining the viewpoint of both the stakeholders and the perspective of legitimacy gives a more holistic view of how these constructs work. The legitimacy-level model explores how previous experience with the government affects the views of individuals and whether decisions on the communication policy of thegovernment align with the views of individuals on legitimacy, performance and corruption. In order to explain these phenomena, they must be studied at the level of contactat which they occur.

More specifically, the theory of stakeholders predicts that increased levels of voluntary disclosure indicate commitments to greater accountability and transparency (Ntim et al., 2012), This can be an important way to gain the support of strong stakeholders, such as donors, politicians, representa tives, the media, civil society organizations and people. Ultimately, the theory of resource dependency predicts that increased voluntary transparency can help to give an organization access to important resources through improved institutional image and credibility (Nikolaeva \& Bicho, 2011).

De Schepper et al (2014) proposed "the creation of a governance structure where both focal organisations are represented formally or informally, which is then responsible for stakeholder identification and inclusion" and concluded that "a governance structure helps to mitigate the trust problems between both focal organisations." It is therefore instructive to take a step back and review the various recommendations suggested and gain new perspectivesto increase performance by approaching stakeholders and gaining credibility. The Stakeholder Salience model has been used to differentiate, prioritize and effectively interact with more relevant or influential stakeholders. The theory of legitimacy implies that corporations are bound by the social contract under which businesses promise to take different socially desired acts in exchange for their aims to be accepted and this essentially ensures their continued existence.

Undoubtedly, Each of the above perspectives has contributed to advancing our understanding of efficiency variables, but most researchers have not paid adequate attention to the issue of stakeholders and legitimacy. Thus, taking a step back and gaining new perspectives to increase performance by addressing stakeholders and credibility is instructive. 8 different stakeholder groups are defined by this model: dormant, latent, demanding, dominant, hazardous, dependent, definitive and non-stakeholders. Moreover, The theory of legitimacy implies that corporations are bound by the social contract under which businesses promise to take different socially desired actsin exchange for theiraims to be accepted and this essentially ensures their continued existence. This mix of hypotheses would help to explain the complex world in which governments work and the means of manipulating the views of stakeholders and gaining legitimacy.

In the company's tactical day-to-day decision making process, a government needs to define its stakeholdersand include theirneedsand values. Therefore, depending on the local circumstances under which it operates, the society under which the government functions and which determines the number of stakeholders to which the government owes a duty can be large. However, Disclosure to stakeholders 
is one significant factor, and with the stakeholder and credibilitylens, this aspect can be better understood. The theory of legitimacy is likely to be the most commonly used theory to describe environmental and social disclosure

The legitimacy theory, according to Ness and Mirza (1991), argues The voluntary disclosure of information about social responsibility may be viewed as a mechanism for lowering political costs. The theory of credibility has been regarded as a generally accepted theory to shed light on a company's social reporting activities. It notes that businesses will take steps to ensure that their practices are clearly valid from the point of view of the society in which the company is expected to function. That is, in the larger social structure of which they are part, they will try to create a rese mblance between social values associated with or indirectly associated with their actions and the norms of appropriate behaviour. The theory of legitimacy describes a social contract between organization and community. Mergel and Bretschneider (2013) postulates that "Organizations aim to create a coherence between the social ideals associated with or suggested by their actions and the standards of appropriate conduct in the broader social structure of which they are part. To the degree that these two belief structures are coherent, we should talk about corporate credibility. There would bea challengeto corporate integrity where there isa real or possible discrepancy between the two value systems. Stakeholder theory (state that The continued life of the organization needs the support of the stakeholders and their permission is necessary and the company's operations are therefore modified according to that approval. The stronger the stakeholders, the more the business needs to adapt. Social disclosure is thus seen as part of the dialogue between the company and its stakeholders (Gray et al., 1995). From the viewpoint of the stakeholder, a company's success depends on its ability to balance the different demands of its differentstakeholders.

\section{Determination}

Communicating with the public is not the supreme aim of a government and its bodies, but it is an essential service for the stakeholders which helpsin generating support for the government's actions. Not seizing the opportunity to communicate at the right moment has its own consequences. Game-changing opportunities may not present themselves again and after-the-event communication may not be effective because by then the damage is done. Haphazard communication, insufficient communication and afterthe-event communication makes work harder for governments. By informing the public, governments can rectify the public perception and accurately represent their activities and the ensuing success and hence gain the public's support and confidence to help the governance structures achieve their objectives.

\section{CONCLUSION}

Lack of trust weakens the impact of all governance efforts. Lack of trust prevents the effective implementation and performance of the structures. If citizens don't trust the procedures, they won't be engaged and ultimately the efforts won't produce the improved performance that policy makers hope to see. To address this issue, a strategic approach can maketrustmore likely to develop. The starting point is to understand the citizens' circumstances asstakeholders, the factors that lead to trustand the process by which trust develops. To nurture trust then becomes a more streamlined process to address the expectations of citizens by making them participate in the decision-making process. Citizens need sufficient and usefulinformation which assists them to makea decision. 


\section{REFERENCES}

Abbas, M. (2018). Good Governance in Islam. Islamic Research Foundation International. Irfi. http://irfi.org/articles/articles_351_400/good_governance_in_islam.htm

Ali, M. M. (2011). Holy Quran. Ahmadiyya Anjuman Ishaat Islam Lahore USA.

Ashraf-Khan, M. . (2018). Anti-Corruption Efforts in the Islamic World: An Investigation. ICIA.

Ayuso, S., Rodríguez, M. A., García-Castro, R., \& Ariño, M. A. (2014). Maximizing stakeholders' interests: An empirical analysis of the stakeholder approach to corporate governance. Business \& Society, 53(3), 414-439.

Bangladesh Institute of Islamic Thought. (2005). Research in Public Administration: An Islamic Perspective.

Bendell, J. (2017). Terms for endearment: Business, NGOs and sustainable development. Routledge.

Bovens, M., Schillemans, T., \& Goodin, R. E. (2014). Public accountability. The Oxford Handbook of Public Accountability, 1(1), 1-22.

Braithwaite, V., \& Levi, M. (1998). Trust and governance. Russell Sage Foundation.

Chapra, M. U. (2016). The future of economics: An Islamic perspective (Vol. 21). Kube Publishing Ltd.

Choudhury, M. A. (2011). Islamic economics and finance: An epistemological inquiry. Emerald Group Publishing.

Colvin, R. M., Witt, G. B., \& Lacey, J. (2016). Approaches to identifying stakeholders in environmental management: Insights from practitioners to go beyond the 'usual suspects.' Land Use Policy, $52,266-276$.

De Schepper, S., Dooms, M., \& Haezendonck, E. (2014). Stakeholder dynamics and responsibilities in Public-Private Partnerships: A mixed experience. International Journal of Project Management, 32(7), 1210-1222.

Denyer, D., \& Tranfield, D. (2006). Using qualitative research synthesis to build an actionable knowledge base. Management Decision.

Devine-Wright, P. (2011). Enhancing local distinctiveness fosters public acceptance of tidal energy: A UK case study. Energy Policy, 39(1), 83-93.

Donaldson, T., \& Preston, L. E. (1995). The stakeholder theory of the corporation: Concepts, evidence, and implications. Academy of Management Review, 20(1), 65-91.

Duit, A., \& Galaz, V. (2008). Governance and complexity-emerging issues for governance theory. Governance, 21(3), 311-335.

Elghuweel, M. I., Ntim, C. G., Opong, K. K., \& Avison, L. (2017). Corporate governance, Islamic governance and earnings management in Oman. Journal of Accounting in Emerging Economies.

Freeman, R. E. (1984). Strategic management: A stakeholder perspective, Boston: Pitman.

George, R. P. (2014). The clash of orthodoxies: Law, religion, and morality in crisis. Open Road Media.

Gray, R., Kouhy, R., \& Lavers, S. (1995). Corporate social and environmental reporting. Accounting, Auditing \& Accountability Journal.

Hamid, A. A., Haniff, M. N., Othman, M. R., \& Salin, A. S. A. P. (2011). The comparison of the characteristics of the Anglo-Saxon governance model and the Islamic governance of IFIs. Management \& Accounting Review (MAR), 10(2), 1-12.

Hopper, T. (2017). Neopatrimonialism, good governance, corruption and accounting in Africa: Idealism vs pragmatism. Journal of Accounting in Emerging Economies.

Hufty, M. (2011). Governance: Exploring four approaches and their relevance to research. Research for Sustainable Development: Foundations, Experiences, and Perspectives, 165-183.

IMF. (2005). Good Governance: The IMF's Role. http://www.imf.org/external/pubs/ft/exrp/gvern/govindex.htm

Kim, C.-K. (2014). Anti-corruption initiatives and e-government: a cross-national study. Public Organization Review, 14(3), 385-396. 
Lerman, A. E., \& Weaver, V. M. (2014). Arresting citizenship: The democratic consequences of American crime control. University of Chicago Press.

Lewis, M. K. (2014). Principles of Islamic corporate governance. In Handbook on Islam and Economic Life. Edward Elgar Publishing.

Mahomedy, A. C. (2013). Islamic economics: Still in search of an identity. International Journal of Social Economics.

Mergel, I., \& Bretschneider, S. I. (2013). A three-stage adoption process for social media use in government. Public Administration Review, 73(3), 390-400.

Mitchell, R. K., Agle, B. R., \& Wood, D. J. (1997). Toward a theory of stakeholder identification and salience: Defining the principle of who and what really counts. Academy of Management Review, 22(4), 853-886.

Moore, M. (2001). Understanding Variations in Political Systems in Developing Countries: A Practical Framework. Unpublished.

Moyo, K. (2017). An analysis of the impact of corruption on the realisation of the right to development. South African Journal on Human Rights, 33(2), 193-213.

Muhamad Sori, Z., Mohamad, S., \& Shah, M. (2015). Shariah governance practices in Malaysian Islamic financial institutions. Available at SSRN 2579174.

Ness, K. E., \& Mirza, A. M. (1991). Corporate social disclosure: A note on a test of agency theory. The British Accounting Review, 23(3), 211-217.

Nikolaeva, R., \& Bicho, M. (2011). The role of institutional and reputational factors in the voluntary adoption of corporate social responsibility reporting standards. Journal of the Academy of Marketing Science, 39(1), 136-157.

Ntim, C. G., Opong, K. K., \& Danbolt, J. (2012). The relative value relevance of shareholder versus stakeholder corporate governance disclosure policy reforms in South Africa. Corporate Governance: An International Review, 20(1), 84-105.

Paler, L. (2013). Keeping the public purse: An experiment in windfalls, taxes, and the incentives to restrain government. American Political Science Review, 706-725.

Phillips, R. (2003). Stakeholder legitimacy. Business Ethics Quarterly, 25-41.

Robichau, R.W. (2011). The mosaic of governance: creating a picture with definitions, theories, and debates. Policy Studies Journal, 39, 113-131.

Rothstein, B. (2011). The quality of government: Corruption, social trust, and inequality in international perspective. University of Chicago Press.

Saito, H., \& Ruhanen, L. (2017). Power in tourism stakeholder collaborations: Power types and power holders. Journal of Hospitality and Tourism Management, 31, 189-196.

Snider, K. F., \& Rendon, R. G. (2012). Public procurement: Public administra tion and public service perspectives. Journal of Public Affairs Education, 18(2), 327-348.

TI (Transparency International). (2017). Corruption Perceptions Index 2017. https://www.transparency.org/news/feature/corruption_perceptions_index_2017

Welter, F., \& Smallbone, D. (2011). Institutional perspectives on entrepreneurial behavior in challenging environments. Journal of Small Business Management, 49(1), 107-125.

Zürn, M. (2018). A theory of global governance: Authority, legitimacy, and contestation. Oxford University Press. 